Egyptian Journal for Aquaculture

ISSN: 2090-7877

www.braesd.org

Hassan etal., 2018; 8(2):17-28

\title{
Genetic Study of Some Egyptian Crabs Species in the Fisheries Grounds
}

Hassan,M.A; ${ }^{1}$ Megahed, M.E ${ }^{\mathbf{2}}$ and Eltayea E. $\mathbf{T}^{\mathbf{1}}$.

1- Department of Animal Production, Faculty of Agriculture, Al-Azhar University, Cairo,Egypt.

2- National Institute of Oceanography and Fisheries (NIOF), Branch of Gulfs of Suez and Aqaba, Attaka, Suez.

Received: July 25, 2018; Accepted: August 19, 2018 Vol.8 (2):17-28

\section{ABSTRACT}

The Random Amplification of Polymorphic DNAPolymerase Chain Reaction (RAPD-PCR) analyses were applied for studying 7 Egyptian populations of crab species. The genetic distance (GD) among close collection sites was small among location 1, 2, 3, 4, 6 and 7, but those between location 5 and 8 were much larger $(0.666$ and 0.833 , respectively). These values between the populations of Lake Timsah, Bitter Lakes, Suez, Attaka, Al-Tur, Port said, Domietta, Rashid and Abo-Qir showed that, AL-Tur population was distantly related from both Lake Timsah, Bitter Lakes, Suez, Attaka, Port-Said, Domietta, Rashid and Abo-Qir populations.

Average of similarity index (SI) values among the studied populations based on RAPD analysis were $0.646,0.229,0.32$, $0.328,0.222$ and 0.338 in respective arrangement between each pair of the populations; S.T.z with E.T.z, S.T.z with S.O. $a u$, S.T.z with E.O.au, E.T.z with S.O.au, E.T.z with E.O.au and S.O.au with E.O.au. Lake Timsah, Bitter Lakes, Suez, Attaka, Al-Tur, Port-Said, Domietta, Rashid and Abo-Qir.

It was stated that the lowest SI value (0.2) was calculated between Rashid and Lake Timsah populations and the highest similarity value (1.00) was calculated between Domietta, Port-Said and Bitter Lakes. However, lower SI values were obtained between Al-Tur and the other studied crab populations. It was emphasized that this 
population appeared with a unique molecular character. Where, there is low migration rate between Al-Tur population and the other studied crab populations. Moreover, the genetic relationships analysis clustered all populations together except Al-Tur population which was distant from the other populations.

Keywords: Crab, Random Amplification of Polymorphic DNA, Similarity Index, Genetic Distance.

\section{Introduction}

Crab became a most popular food items which command high prices in the national and international markets. In India, the most important species supporting the crab fisheries were Scylla serrata, Scylla tranquebarica, Portunus pelagicus, Portunus sanguinolentus, Charybdis feriata, Charybdis lucifera and Charybdis truncata. It is worth to mention that Portuns pelagicus is one of the commercially important crabs along the Parangipettai coast and has a great demand for their esteemed seafood delicacy and also the value of fishery they support. They are heavily exploited from the Parangipettai coast due to their high demand in local and foreign markets (Alfred-Ockiya, 2000).

Although all large crabs species are edible, most marine crabs of commercial importance belong to three families: Portunidae (swimming crabs), Xanthidae (mud crabs) and Cancridae (cancer crabs). In most West African countries, crabs are an important source of animal protein for coastal and riverine communities; hence most published works deal with their nutritional composition (Alfred-Ockiya, 2000; and Oduro et al., 2001) and ecology (Okafor, 1988 ; Lawal-Are and Kusemiju, 2000). Few studies were carried out on their morphometrics, although this resource has been exploited locally (Anetekhai et al., 1994).

In order to manage the blue crab fishery better, more and more attention and effort have been drawn to the studies of biology, ecology, population genetics and fisheries of the blue crab. It is necessary to use a convenient and economic tagging technique to assess success of the stock enhancement.

Due to some merits, the coded microwire tag has been applied for tagging juvenile blue crabs rather than external tags. It is retained during the molts of crabs and doesn't affect the survival and growth of the crabs (Fitz and Wiegert, 1991). Utilization of this kind of tag is expensive and more importantly extremely labor intensive. It became infeasible when 
hundreds of thousands of crabs or juveniles less than C5 are to be tagged. In contrast, inherent genetic tags are universal regardless of size or number. This work was conducted for studying some Egyptian commercially carp species genetically in the fisheries grounds.

\section{Samples collection:}

\section{Materials and Methods}

Samples were obtained from Lake Timsah, Bitter Lakes, Suez, Attaka, Al-Tur, Port- Said, Domietta, Rashid and Abo-Qir (Fig. 1). From each location, 40 individuals were collected for undergoing to the genetic study of these populations using RAPD-analysis.

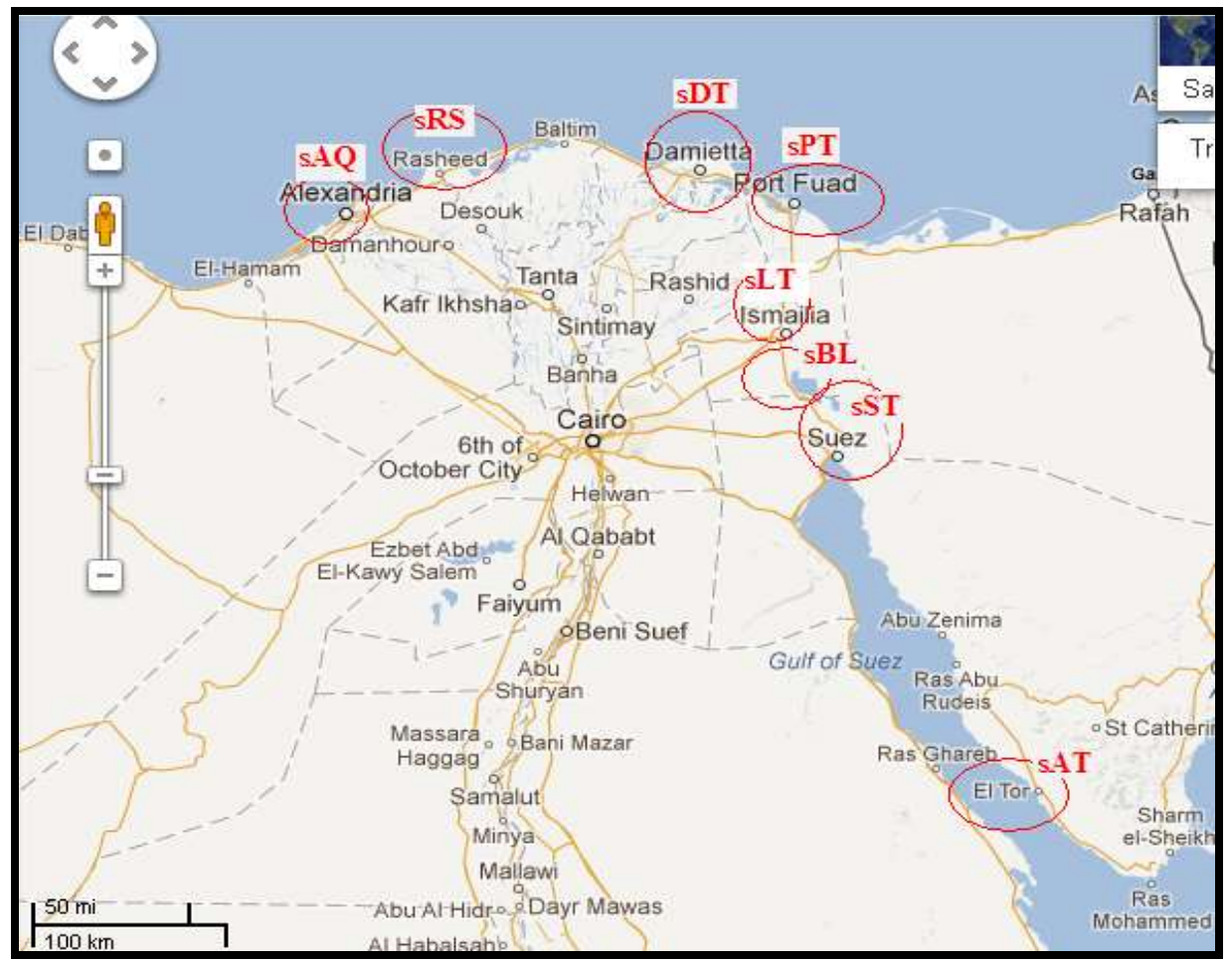

Fig. 1: Map shows the geographic sampling sites.

\section{DNA extraction and amplification:}

The DNA extraction was performed using DNeasy Mini Kit (QIAGEN) following the manual instruction.

Randomly Amplified of Polymorphic DNA-Polymerase Chain Reaction (RAPD-PCR): 
The PCR reaction was carried out with random decamer primers in a $25 \mu \mathrm{l}$ reaction volume containing $18 \mu \mathrm{L}$ double-distilled water, $2.5 \mu \mathrm{L}$ (10X) buffer, $1.5 \mathrm{mM} \mathrm{MgCl}, 0.5 \mu \mathrm{L}(10 \mathrm{mM})$ dNTP mix, $1 \mathrm{U}$ Taq polymerase, $2 \mu \mathrm{L}$ of each primer, $1 \mu \mathrm{L} \mathrm{BSA}$, and $20-30 \mathrm{ng}$ of the template DNA.

RAPD-PCR was performed in a thermal cycler for 40 cycles consisting of denaturation at $94^{\circ} \mathrm{C}$ for 40 seconds, annealing at $36^{\circ} \mathrm{C}$ for 50 seconds, and extension at $72^{\circ} \mathrm{C}$ for 60 seconds. The final extension was carried out at the same temperature for 5 minutes. The amplified product was checked in 1.5\% agarose gel electrophoresis and bands were observed in gel documentation system. The PCRs were carried out with a set of decamer primers. As illustrated in Table 1, 9 primers (Operon technologies, Inc.; Alameda, California, EUA) were initially screened for reproducible and scoreable amplified bands.

Table 1: Primers RAPD used for PCR amplification.

\begin{tabular}{cc}
\hline Primer code & The sequence (5'-3') \\
\hline A7 & 5'-GAAACGGGTG-3' \\
A10 & 5'-GTGATCGCAG-3' \\
A18 & 5'-AGGTGACCGT-3' \\
B13 & 5'-TTCCCC CGCT-3' \\
C3 & 5'-GGGGGTCTTT-3' \\
C7 & 5'-GTCCCGACGA-3' \\
C8 & 5'-TGGACCGGTG-3' \\
C9 & 5'-CTCACCGTCC-3' \\
OPO-04 & 5'-CCGCATCTAC-3' \\
\hline
\end{tabular}

\section{Data analysis:}

After DNA electrophoresis, agarose gels were photographed by Gel documentation system and analyzed using Quantity One software (Version 4.6.2). The similarity index (SI.) compares patterns within, as well as, between irradiated and non-irradiated samples using the formula:

$$
\text { Sxy= 2nxy / (nx + ny) (Nei and Li, 1979). }
$$

Where :

- $\mathbf{n x y}$ is the number of bands shared by $\mathrm{x}$ and $\mathrm{y}$ individuals.

- nx and ny are the numbers of bands scored for each individual.

- Sxy is the similarity index between $\mathrm{x}$ and $\mathrm{y}$ individuals. 
Similarity within populations (homogeneity) was calculated as an average of Sxy across all possible comparisons between individuals within such population as described by (Lynch, 1990). The similarity values were converted into genetic distance (GD) using the formula: GD $=\mathbf{1}$ - S.I.

The value produced by this index ranges from zero, representing no bands sharing, to (1), representing complete identity, while G.D is the genetic distance value. The dendrogram which describes phylogenetic relationships among studied populations was constructed according to Sneath and Sokal (1973).

\section{Results and Discussion}

The genetic variations among crab samples collected from different locations in coastal water of Egypt:

A total of 120 distinct bands were obtained from 8 DNA samples (The samples collected from each location pooled together to be one sample, 40 samples pooled to 8 samples). From the RAPD-DNA fingerprinting, it was noticed that $\boldsymbol{c r a b}$ (Lane 1) has typical bands 1, 2 and 5 using primer OPO-04. $\boldsymbol{c r a b}$ (Lane 8) has the other strong typical bands 3 and 4. $\boldsymbol{c r a b}$ Lanes 2 to 7 indicated continuous variation of fingerprinting pattern among the sample location (Fig. 2). The results using other primers did not give enough variation compared to that of primer OPO-04.

The data compiled in Table 2 showed that the SI and GD values calculated from the DNA fingerprinting using different primers. The GD became evident that the value among close collection sites was small among location 1, 2, 3, 4, 6 and 7, but those between location 5 and 8 were much larger ( 0.666 and 0.833 , respectively).

As presented in Fig. 2, the dendrogram obtained from the SI values by cluster analysis indicated that crab can be completely isolated from the other species. It has been judged that these genetic differences are promising to collect the $\boldsymbol{c r a b}$ from different distantly far locations to have wide genetic variations to be basis for domestication and selection.

The extent to which the RAPD fragments shared among populations of Lake Timsah, Bitter Lakes, Suez, Attaka, Al-Tur, Port said, Damietta, Rashid and Abo-Qir was quantitatively reflected in calculating the similarity coefficient (Table 2). Moreover, the RAPD fragments were represented qualitatively from the dendrogram based on DNA markers (Fig. 2). It was showed that Al-Tur population was distantly related from each of Lake Timsah, Bitter Lakes, Suez, 
Attaka, Port Said, Damietta, Rashid and Abo-Qir populations. The lowest SI value (20) was calculated between Rashid and Lake Timsah populations and the highest value (100) was calculated between Domietta, Port-Said and Bitter Lakes populations concerning the RAPD results.

Previous studies demonstrated that the RAPD method is powerful tool to assessment of genetic markers in Fish (Ahmeeda and Sodre., 2002 ; Huang and Chen, 2003 ; Saad et al., 2009).

Table 2: The similarity index (SI) values between locations based on RAPD- PCR.

\begin{tabular}{|c|c|c|c|c|c|c|c|c|c|}
\hline & LT & BT & SA & $\mathbf{T u}$ & $\mathbf{P t}$ & Dm & $\mathbf{R a}$ & Qi \\
\hline & & \multicolumn{8}{|c|}{ GD } \\
\hline LT & \multirow{8}{*}{ SI } & 100 & 40 & 40 & 20 & 40 & 40 & 80 & 40 \\
\hline BT & & 60 & 100 & 50 & 25 & 0 & 0 & 67 & 50 \\
\hline SA & & 60 & 50 & 100 & 25 & 50 & 50 & 100 & 50 \\
\hline $\mathbf{T u}$ & & 80 & 75 & 75 & 100 & 25 & 25 & 75 & 25 \\
\hline $\mathbf{P t}$ & & 60 & 100 & 50 & 75 & 100 & 0 & 67 & 50 \\
\hline Dm & & 60 & 100 & 50 & 75 & 100 & 100 & 67 & 50 \\
\hline $\mathbf{R a}$ & & 20 & 33 & 0 & 25 & 33 & 33 & 100 & 67 \\
\hline Qi & & 60 & 50 & 50 & 75 & 50 & 50 & 33 & 100 \\
\hline
\end{tabular}
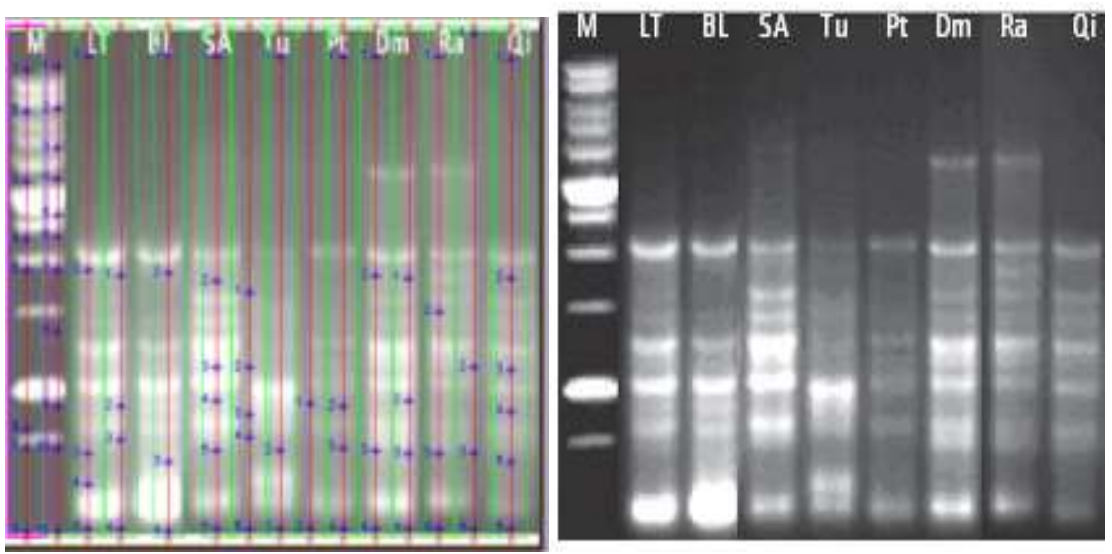

Fig. 2: RAPD-PCR analysis of the $c r a b$ studied in the different environments using primer 2 (OPA04). Agarose gel electrophoresis showing the separation of RAPD PCR products onto $1.5 \%$ SeaKem GTG agarose containing 0.5 $\mathrm{ug} / \mathrm{ml}$ ethidium bromide. 

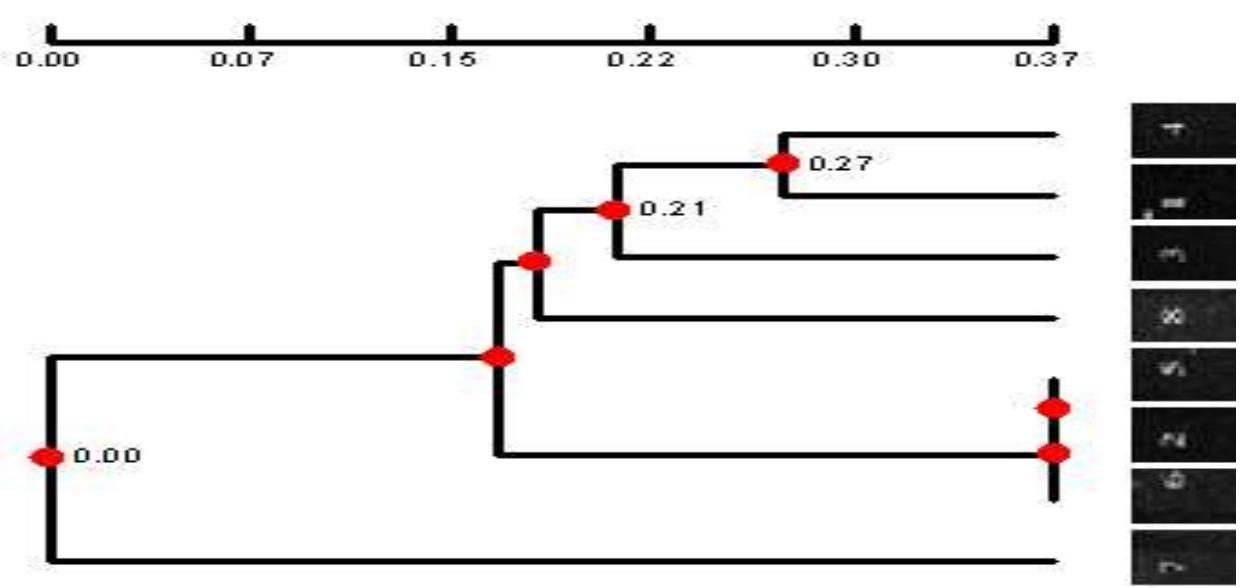

Fig. 3: Phylogenetic relationships between locations based on RAPD analysis.

In the present study, all primers yielded satisfactory amplification products with all specimens tested. Each primer produced a unique band pattern of amplified DNA. In addition, the analysis of RAPD data succeeded in screening the variations among the applied crab populations. The Low similarity values were detected between AL-Tur and the other studied crab populations. This reflected that this population has a unique molecular character. This reflected that, there is low migration rate between Al-Tur population and the other studied crab populations.

However, knowledge of its genetic population structure is lacking, although this could provide important information for effective fisheries and aquaculture management. On the other hand, there are increasing evidence that the RAPD technique can detect nuclear DNA variation in fishes between subspecies, or populations of the same species (Williams et al., 1990 ; Bardakci and Skibinski, 1994 ; Naish et al., 1995).

Furthermore, Ibrahim et al. (2005) detected the genetic characterization of some Egyptian and Syrian Tilapia population among 4 Tilapia populations (Egyptian T.zillii and O.aureus populations denoted as E.T.z and E.O.au; Syrian T.zillii and O.aureus denoted S.T.z and S.O.au, respectively).

During the current study, the molecular genetic structure of the relevant populations was investigated. The average SI values among the 
studied populations based on RAPD analysis between each pair of the following populations: S.T.z with E.T.z, S.T.z with S.O.au, S.T.z with E.O.au, E.T.z with S.O.au, E.T.z with E.O.au and S.O.au with E.O.au were represented by $0.646,0.229,0.32,0.328,0.222$ and 0.338 , respectively.

The RAPD assay was evaluated for studying genetic relationships and diversities in four species of Indian major carps (Family Cyprinidae). Thirty-four arbitrary primers were screened to identify species-specific RAPD markers among rohu (Labeo rohita), kalbasu (L. calbasu), catla (Catla catla) and mrigal (Cirrhinus mrigala) (Barman et al., 2003).

However, RAPD comparisons are based on the assumption that bands of the same molecular weight and amplified with the same primer represent homologous DNA sequences. Nevertheless, RAPD markers remain a powerful tool to detect genetic polymorphism in closely related organisms, as confirmed by numerous studies. These observations suggested that comparisons up to the family level are more likely to be reliable (Hung et al., 2005).

While, Mamuris et al., (1998) reported that organisms such as marine fishes and striped red mullet in particular with very large populations were expected to have larger Hs. The large value of $\mathrm{H}$, therefore implies that striped red mullet had a long unbroken history in the Mediterranean Sea without population bottle necks. They reported similar results for red mullet (Mullus barbatus). Also, they found that RAPD failed to produce specific markers could discriminate populations, but was successful in revealing genetic heterogeneity between samples. Moreover, they conducted that the RAPD method is suitable for identification of species and for differentiating among populations particularly in cases of, where the morphological characters do not permit an unambiguous or rapid identification of species.

Almeida et al. (2011) studied to detect the genetic polymorphism in different species or different populations of the same species using RAPD technique. Some RAPD results follow the geographical distance but others not. This occurred in different fishes and different locations (Ambak et al., 2006 ; Bektas and Belduz, 2007 ; Saad et al., 2009). 
This method has been successfully used to detect the variations among different fish populations and the results of these studies agreement with the author researchers such as (Bardakci and Skibinski, 1994). They used 13 random primers to evaluate the similarity among three species of Tilapia genus Oreochromis and four subspecies of Oreochromis niloticus. They found that, all primers gave species-specific DNA marker by RAPD technique and RAPD analysis has been applied for the identification of fish species as well as for monitoring the genetic changes in the acclimation of the European sea bass to freshwater (Partis and Wells, 1996).

Our findings were supported by Rashed et al., (2008) who used RAPD technique to detect the genetic diversity and construct the phylogenetic relationships of some Egyptian Nile Tilapia (Oreochromis niloticus) populations collected from (Aswan-Nasser Lake, Giza and Quanater) locations. The dendrogram showed that Quanater is more distant from the other two populations (Aswan and Giza).They suggested that the smaller geographical distance between Aswan and Giza permits the higher gene flow between them and so lower genetic distance.

In conclusion, the RAPD technique can provide useful genetic information on Crap that could be valuable for stock structure analysis. Furthermore, populations specific genetic markers that were determined during the present study can be used as a marker assisted selection in the breeding programmes of the Crap to improve the Crap performance. Use of the genetic markers in breeding programmes and in supportive genetic research is strongly urged in order to minimize incorrect identification and stock contaminate.

\section{References}

Ahmeeda, F.S. and L.M.K. Sodre (2002). Comparative study by RAPD analysis of six species of the pimelodidae family (Osteichthyes, siluriformes) from the Tibagi River, State of Paranà, Brazil. Maringà, 24 (2): 513-517.

Alfred-Ockiya,J.F. (2000).Nutritional changes in traditionally preserved Shellfishes from the NigerDelta. Nigeria,J. Aquat. Sci., 15: 9-11.

Almeida, F.S ; M.H.P. Fungaro and L.M.K. Sodre (2011). RAPD and isozyme analysis of genetic variability in three allied species of catfish 
(Siluriformes: pimelodidae) from the Tibagi River. Brazil, J. Zool. United Kingdom, 253 (1): 113 -120.

Ambak, M.A. ; A.M.A. Bolong ; P. Ismail and B.M. Tam (2006). Genetic variation of snakehead fish (Channa striata) populations using random amplified polymorphic DNA. Biotechnology, 5 (1): 104- 110.

Anetekhai, M.A. ; F.G. Owodeinde and F.G. Ogbe (1994). Meristic and morphometric features, age and growth pattern in Cardiosoma armatum (Herklots) from Lagos lagoon, Nigeria. Nig. J. Sci., 19 (1): 12-18.

Bardakci, F. and D.O.F. Skibinski (1994). Application of RAPD technique in tilapia fish: Species and subspecies identification. Heredity, 73: 117-123.

Barman, H.K. ; A. Barat ; B.M. Yadav ; S. Banerjee ; P.K. Meher ; P.V.G.K. Reddy and R.K. Jana (2003). Genetic variation between four species of Indian major carps as revealed by random amplified polymorphic DNA assay. Aquaculture, 217 : 115-123.

Bektas, Y. and A.O. Belduz (2007). Molecular characterization of the whiting (Merlangius merlanguse uxinus Nordman, 1840) in Turkish Black Sea Coast by RAPD analysis. J. Anim. Vet. Adv., 6(5): 739744.

Fitz, H.C. and R.G. Wiegert (1991). Tagging juvenile blue crabs, Callinectes-sapidus with microwire tags - retention, survival, and growth through multiple molts. Journal of Crustacean Biology, 11(2): 229-235.

Huang, G.C. and D.J. Chen (2003) Evaluation of genetic variability in Taiwan endemic catfish, Clarias fuscus species using RAPD markers. J. Fish. Soc., 30(3): 253-262.

Hung, C. ; L.Y. Hsuan, and D.J. Chen (2005). The use of RAPD markers to assess catfish hybridization. Biodiversity and Conservation, 14 (12): 3003-3014.

Ibrahim, M.M. ; M.A. Rashed, ; A.A. El-Seoudy and Y.M. Saad (2005). Genetic characterization of some Egyptian and Syrian Tilapia population. The second Syrian - Egyptian Symposium of Agriculture and Food sin Arab world (actuality and future challenges).

Lawal-Are, A.O. and K. Kusemiju (2000). Size composition, growth 
pattern and feeding habits of the blue crab, Callinectes amnicola (De Rocheburne) in the Badagry Lagoon, Nigeria. J. Sci. Dev., 4: 117-126.

Lynch, M. (1990). The Similarity Index and DNA Fingerprinting .Mol. Biol. Evol., 7(5): 478-484.

Mamuris, B.G. ; L. Sola, and D.E. Campton (1998). Used the random amplified polymorphic DNA(RAPD ) technique to evaluate genetic affinities among eight red mullet (Mullus barbatus L., 1758). Mar Biol., 130: $200-210$.

Naish, K.A. ; M. Warren, ; F. Bardakci, ; D.O. Skibinski, ; G.R. Carvalho, and G.C. Mair (1995). Multilocus DNA fingerprinting and RAPD reveal similar genetic relationships between strains of Oreochromis niloticus (Pisces: Cichlidae). Mol. Ecol., 4(2): 271-274.

Nei, M. and W.S. Li (1979). Mathematical model for studing genetic variation in terms of restriction endonuclease. Proc. Natl. Acad. Sci., USA, 76: 5269-5273.

Oduro, W. ; W.O. Ellis, ; I. Oduro, and D. Tetteh (2001). Nutritional quality of selected Ghanaian crab species. J. Ghana Sci. Ass., 3: 3740.

Okafor, F.C. (1988). The ecology of Sudanonautes africanus (Crustacea: Decapoda) in southeastern Nigeria. Trop. Ecol., 29: 89-97.

Partis, L. and R.J. Wells (1996). Identification of fish species using random amplified polymorphic DNA (RAPD). Molecular and cellular probes 10(6): 435.

Rashed, M.A. ; Y.M. Saad, ; M.M. Ibrahim, and A. El-Seoudy (2008). Genetic structure of natural Egyptian Oreochromis niloticus evaluated using dominant DNA markers. Global Veterinaria, 2 (2): 87-91.

Saad, Y.M. ; A.A. Mansour and A.M. El-Nagar (2009). Monitoring of genetic polymorphism in some tilapia species based on fin tissues isozyme distributions. World J. Zool., 4(1): 24 - 28.

Sneath, P.H.A. and R.R. Sokal (1973). Numerical Taxonomy. W.H. Freeman, San Francisco.

Williams, J.G.K. ; A.R. Kubekik, ; K.J. Livak, ; J.A. Afalski and S.V. Tingey (1990). DNA polymorphism amplified by arbitrary primers are useful as genetic markers. Nuclic. Acids Research, 18 (22): 65316535 . 


\section{دراسات وراثيه على بعض أنواع الكابوريا فى المصايد المصرية

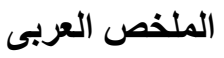

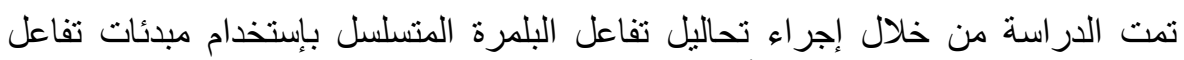

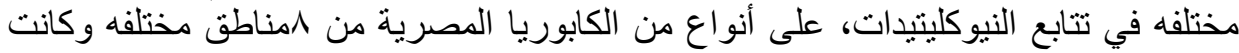

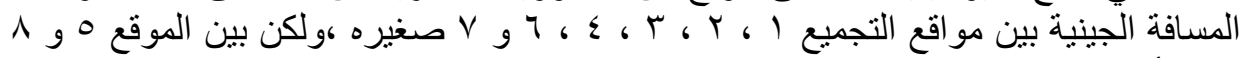

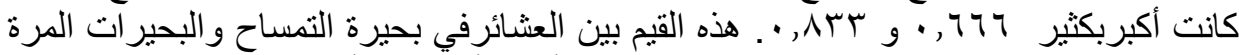

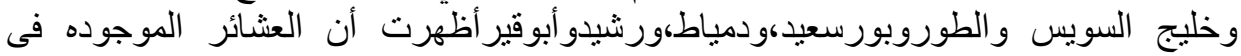

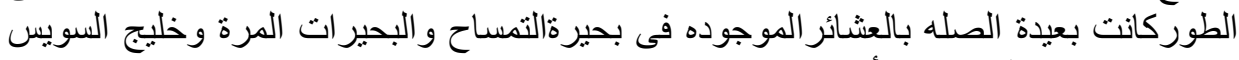
وبورسعيد ودمياط ورشيد و أبوقير.

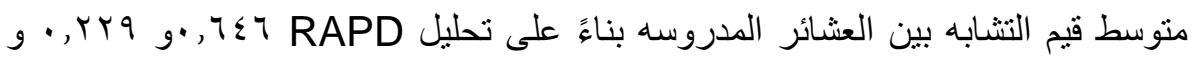

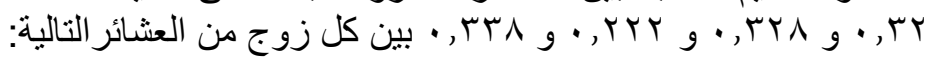

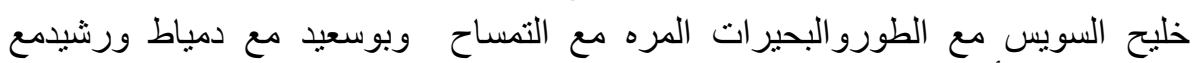

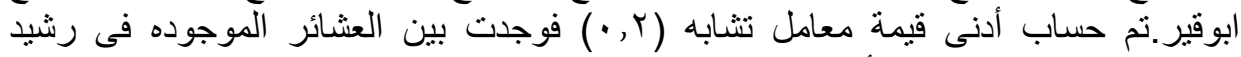

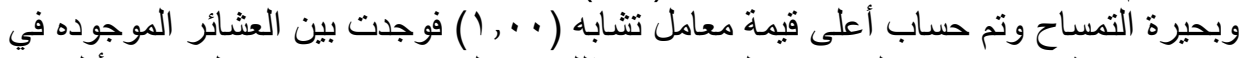

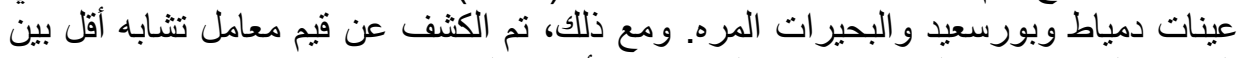

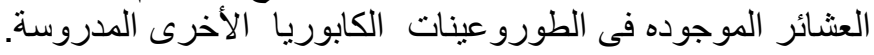

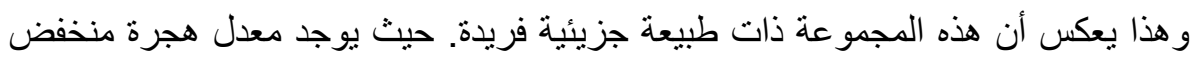

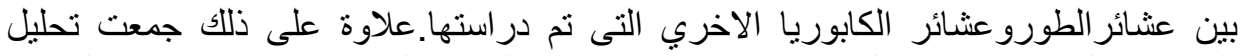

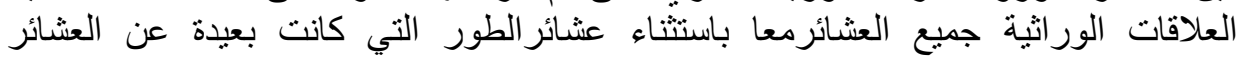
الآخري.

الكلمات الدالة: الكابوريا، تفاعل البلمرة المتسلسل، معامل التشابه، المسافة الجينية. 